\title{
GAMMA RADIATION IN PAPAYA HARVESTED AT THREE STAGES OF MATURATION
}

\author{
Rodrigo Meirelles de Azevedo Pimentel; Julio Marcos Melges Walder* \\ USP/CENA - Lab. de Irradiação de Alimentos, C.P. 96 - 13400-970 - Piracicaba, SP - Brasil. \\ *Corresponding author 〈jmwalder@cena.usp.br>
}

\begin{abstract}
Papaya is a fragile, perishable fruit, highly accepted worldwide. To keep the quality of papaya from harvest to the consumers, conservation techniques are often used; among them is the application of gamma irradiation. The objective of this work was to evaluate gamma irradiation in papayas harvested at three degrees of maturation, in order to increase shelf life. Papayas were harvested in perfect quality conditions and selected by skin coloration into three distinct degrees of maturation: maturation 0 , or beginning of yellow coloration; maturation 1, yellow stripes more developed, and maturation 2, one third yellow. Half of them were irradiated with $0.75 \mathrm{kGy}$, while the other half became control treatment. They were analyzed in four periods of conservation, which were $1 \mathrm{DAI}$ (days after irradiation refrigerated at $11 \pm 1^{\circ} \mathrm{C}$ ), $14 \mathrm{DAI}, 14 \mathrm{DAI}$ $+3 \mathrm{DRT}$ (room temperature at $24^{\circ} \pm 2^{\circ} \mathrm{C}$ ) and $14 \mathrm{DAI}+6 \mathrm{DRT}$. The papaya maturation degree at harvest did not influence the radiation effect. Irradiation maintained firmness of papaya and, therefore, delayed ripening; modified the green color of papaya to a lighter, more intense tone, which determined more homogeneity in the development of the skin's yellow color (greater values of $\mathrm{L}^{*}$ and croma). There was no effect of irradiation in papaya weight loss, occurrence of diseases, croma of flesh color, $\mathrm{pH}$ and total soluble solids contents. Key words: post-harvest, food conservation, gamma irradiation, tropical fruits, shelf life
\end{abstract}

\section{RADIAÇÃO GAMA EM MAMÃO PAPAIA COLHIDO EM TRÊS ESTÁDIOS DE MATURAÇÃO}

\begin{abstract}
RESUMO: O mamão é um fruto frágil, perecível, muito apreciado mundialmente. Para que a qualidade do mamão se mantenha da colheita até os consumidores, técnicas de conservação são utilizadas, sendo uma destas a aplicação de radiação gama. O objetivo deste trabalho foi avaliar a aplicação de irradiação gama em mamões colhidos em diferentes estádios de maturação com a intenção de aumentar a vida útil pós-colheita. Mamões foram colhidos em perfeitas condições de qualidade e selecionados pela coloração amarela em três fases distintas: maturação 0 , ou início da coloração amarela; maturação 1, com estrias amarelas mais desenvolvidas, e maturação 2, com um terço da casca já amarelo. Metade destes foi irradiada com 0,75 kGy e a outra se tornou testemunhas. A análise se deu em quatro períodos de conservação sendo estes 1 DAI (dias após a irradiação sob refrigeração a $11 \pm 1^{\circ} \mathrm{C}$ ), 14 DAI, 14 DAI + 3 DTA (dias a temperatura ambiente a $24^{\circ}$ $\pm 2{ }^{\circ} \mathrm{C}$ ) e 14 DAI +6 DTA. Não houve diferença entre os mamões irradiados em diferentes estádios de maturação. A irradiação promoveu manutenção da firmeza do mamão e, portanto, retardo no amadurecimento; modificou a cor verde do mamão para tons mais claros e mais intensos o que determinou maior homogeneidade no desenvolvimento da cor amarela da casca (valores de brilho e croma maiores). Não houve efeito da irradiação na perda de massa, aparecimento de doenças, na cor interna dos frutos, no $\mathrm{pH}$ e no teor de sólidos solúveis. Palavras-chave: pós-colheita, conservação de alimentos, vida de prateleira, irradiação gama, frutas tropicais
\end{abstract}

\section{INTRODUCTION}

Papaya is a tropical fruit of great acceptance and of increasing economical importance in Brazil. Brazil is the world's largest papaya producer, but exports, only a small fraction of its total production which, however, has increased in the past few years (FAO, 2002).

Because papaya is naturally fragile, it is a target to many post-harvest injuries and mechanical damages due to its thin skin. Papaya also cannot resist low temperatures, increasing the difficulties in its storage, and finally, for the entering in some countries, needs to undergo approbatory efficiency of quarantine treatments against fruit flies (Bleinroth, 1995).

Gamma irradiation in low doses has satisfactorily increased papaya's shelf life by delaying the ripening process and senescence; it is also effective in the quarantine treatment against fruit flies (Thomas, 1986). Moreover, using the technique combined to hot water dip, papaya shelf life could be extended by reducing fungal rots.

The optimum dose for ripening delay in papaya is $0.75 \mathrm{kGy}$, which preserves papaya firmness for a longer time (Moy, 1977; Akamine \& Wong, 1966; Akamine \& 
Goo, 1977). However, conflicting results have been presented regarding definition of the maturation stage of papaya at the moment of irradiation, since its efficiency in delaying the ripening process will depend on the maturation stage. According to Urbain, (1986), Akamine \& Goo (1977), and Bleinroth (1995) papaya should be in the pre-climacteric phase, which means, before it reaches $1 / 4$ yellow to be irradiate. But, according to Paull (1995) and Zhao et al. (1996), who studied irradiation effects in many maturation stages, best results are attained when papayas are $30 \%$ yellow.

Abiding to requirement of fruit fly quarantine, necessary to get permits to export papaya to the United States, for instance, papaya must be harvested unripe at the beginning of the yellowing phase (Malavasi, 1996). However, the stage of maturation in the moment of harvest is imperative to the organoleptic quality of papaya. The main component in the quality of papaya is sugar content, and the greater the time the fruit remains in the tree before harvest, the higher will be its soluble solids content (Akamine \& Goo, 1971).

Irradiation treatment control fruit flies in papaya with extreme efficiency, allowing the harvest to occur in a more advanced stage of maturation, conferring better quality to papaya. The objective of this work was the evaluation of post-harvest quality of papaya, harvested in three different stages of maturation and submitted to gamma irradiation for ripening delay.

\section{MATERIAL AND METHODS}

Type-Solo papayas were harvested in Sooretama, ES $\left(19^{\circ} 24^{\prime} \mathrm{S}, 40^{\circ} 04^{\prime} \mathrm{W}\right)$, in perfect quality conditions, washed, waxed with carnauba wax and selected by intensity of yellow color in three distinct phases, defined as maturation 0 , or beginning of yellow color up to $10 \%$ of yellow surface; maturation 1, with more developed yellow stripes or up to $20 \%$ of yellow surface; and maturation 2, with up to one third of yellow skin. This selection was adapted from the Systems Approach which employ pre and post-harvest practices to guarantee fruits free of fruit flies (Brasil, 2000). Upon arrival to the food irradiation laboratory, fruits were submitted to new selection by color to set respective treatments, defined by a treble factorial scheme, where papayas in three stages of maturation were either treated by irradiation with 0.75 kGy or not, and analyzed in 4 different periods of conservation, which was $1 \mathrm{DAI}$ (days after irradiation under refrigeration of $11 \pm 1^{\circ} \mathrm{C}$ and $\left.\mathrm{RH} 80-90 \%\right) ; 14 \mathrm{DAI} ; 14$ DAI + 3 DRT (days at room temperature $24^{\circ} \pm 2^{\circ} \mathrm{C}$ ); and 14 DAI + 6 DRT.

The irradiation was done in the day after fruit selection, at the rate $0.393 \mathrm{kGy} \mathrm{h}^{-1}$, through a Cobalt-60 source type Gammabeam 650 (Atomic Energy of Canada Ltd.), available at CENA/USP.
Trials were set up in a totally randomized design, factorial scheme $2 \times 3 \times 4$ (dose $\times$ maturation stage $\mathrm{x}$ period of storage), with four replications in a total of 96 samples, each sample represented by one papaya. each sample:

The following analysis were accomplished for

Phytossanitary quality: using the method of category scales in the evaluation of disease signs. The assessment of this characteristic was done subjectively through scores related to the following scale adapted from Azevedo (1998): 1. very bad - more than 50\% of fruit with lesions, impossible to be made good use of; 2 . bad - lesions between 25 and $50 \%$ of fruit, not much exploitable; 3. tolerable - lesions between 5 and $25 \%$ of fruit, not acceptable for trading, usable to be consumed at home; 4 . Good - lesions up to 5\% of fruit, conditions acceptable for trading; 5. Excellent - without lesions, perfect phytossanitary quality.

Firmness: determined through a digital Fruit Firmness Tester, flat pointed, diameter $0.8 \mathrm{~cm}$. Three measurements per fruit were done in the equatorial region, and expressed in Newtons $(\mathrm{N})$.

External color: determined by Chroma Meter Minolta CR 200b taking three measurements per fruit in the equatorial region. The results were expressed in color lightness $\left(\mathrm{L}^{*}\right)$, chroma $\left(\mathrm{C}^{*}\right)$ and hue angle $\left({ }^{\circ} \mathrm{h}\right)$, according to McGuire (1992), considering the mean value of the three measurements.

Internal color: determined by Chroma Meter Minolta CR $200 \mathrm{~b}$, where two measurements were taken in the internal surface in the equatorial region of fruits after longitudinal cut. The results were expressed in color lightness $\left(\mathrm{L}^{*}\right)$ and chroma $\left(\mathrm{C}^{*}\right)$ considering the mean value of the two measurements.

Total soluble solids (TSS): determined by the use of a refractometer Auto Abbe, the measurement was accomplished directly from the pulp and expressed in percentage.

pH: determined by using the $\mathrm{pH}$ meter Methron Fluisau Modelo E520 directly from the pulp.

Mass loss: determined by difference between initial mass one day before irradiation and mass at the final of the evaluation periods during storage, using a digital scale; results expressed as percentage of mass loss.

ANOVA was performed for all dependent variables. Significant result $(F=0.05)$ led to a continuation of the analysis upon factors with significant results or interactions $(F=0.05)$, and decomposition of the involved 
factors. In both cases, Duncan test was chosen for multiple comparisons of treatments means $(\alpha=0.05)$. All factors were considered qualitative including period of conservation, since during this period papaya was stored at different temperatures.

\section{RESULTS AND DISCUSSION}

Evaluation of phytossanitary quality of papaya revealed interaction between maturation stage and conservation period (Table 1), which confirmed riper papaya to be less disease tolerant. Irradiation of papaya was not efficient in phytossanitary control, since there was no difference to the non-irradiated samples. Moy et al. (1973) and Akamine \& Wong (1966) obtained good phytossanitary control only by combining irradiation and hot water dip, demonstrating treatment synergism. On the other hand, irradiation did not increase disease incidence, differing from Clarke (1971), who affirmed that irradiation increases fruit sensibility to decay. Results about fruit irradiation vary for many reasons (Moy, 1977), one of than being degree of initial infection of fruit before irradiation, that should be low for treatment success.
Analisis of firmness, revealed interaction between conservation period and irradiation (Table 2). Firmness of non irradiated papayas decreased with extending conservation period. There was no difference in firmness between papayas of the three maturation stages, even though they presented different degrees of coloration. Irradiated papayas had higher firmness stability along the conservation period. In the last analysis period, papayas lost some firmness, but remained still much firmer than the non-irradiated control. In relation to the control, Irradiated papaya presented firmer than control in the $3^{\text {rd }}$ and $4^{\text {th }}$ analysis periods. Reports by Akamine \& Wong (1966), Moy et al. (1973), Yasir (1990), and Zhao et al. (1996), in which firmness preservation was the criteria used by the authors to explain the delay of ripening support this result, since yellow color developed normally.

Surface coloration and fruit softening are associated to ripening (Akamine \& Wong, 1966). Normally, papaya is ripen and edible when starts to soften, despite the degree of coloration, which means that edible fruits do not necessarily have to be totally yellow. Actually, totally yellow papayas are in many occasions already senescent. Therefore, regarding papayas, softening is a better indicator of ripening than yellow skin development.

Table 1 - Phytossanitary quality, hue angle and percentage of total soluble solids of papaya in function of conservation period and maturation stage.

\begin{tabular}{|c|c|c|c|c|}
\hline \multirow[b]{2}{*}{ Maturation stages } & \multicolumn{4}{|c|}{ Conservation period } \\
\hline & $1 \mathrm{DAI}$ & 14 DAI & $14 \mathrm{DAI}+3 \mathrm{DRT}$ & $14 \mathrm{DAI}+6 \mathrm{DRT}$ \\
\hline & \multicolumn{4}{|c|}{ Phytossanitary quality } \\
\hline Maturation 0 & $5.00 \mathrm{aA}$ & $5.00 \mathrm{aA}$ & $5.00 \mathrm{aA}$ & $4.13 \mathrm{bA}$ \\
\hline Maturation 1 & $5.00 \mathrm{aA}$ & $5.00 \mathrm{aA}$ & $4.13 \mathrm{bB}$ & $3.25 \mathrm{cAB}$ \\
\hline \multirow[t]{2}{*}{ Maturation 2} & $5.00 \mathrm{aA}$ & $4.63 \mathrm{aB}$ & $3.75 \mathrm{bB}$ & $2.50 \mathrm{cB}$ \\
\hline & \multicolumn{4}{|c|}{ Hue angle } \\
\hline Maturation 0 & $113.05 \mathrm{aA}$ & $107.51 \mathrm{bA}$ & $88.51 \mathrm{cA}$ & $78.36 \mathrm{dA}$ \\
\hline Maturation 1 & $109.20 \mathrm{aB}$ & $100.97 \mathrm{bB}$ & $85.13 \mathrm{cB}$ & $75.65 \mathrm{~dB}$ \\
\hline \multirow[t]{2}{*}{ Maturation 2} & $104.37 \mathrm{aC}$ & $95.05 \mathrm{bC}$ & $82.62 \mathrm{cB}$ & $73.15 \mathrm{~dB}$ \\
\hline & \multicolumn{4}{|c|}{ Percentage of total soluble solids } \\
\hline Maturation 0 & $13.65 \mathrm{bC}$ & $13.79 \mathrm{bB}$ & $14.00 \mathrm{abB}$ & $14.64 \mathrm{aA}$ \\
\hline Maturation 1 & $14.78 \mathrm{bB}$ & $15.65 \mathrm{aA}$ & $15.13 \mathrm{abA}$ & $14.88 \mathrm{bA}$ \\
\hline Maturation 2 & $15.54 \mathrm{abA}$ & $15.90 \mathrm{aA}$ & $14.99 \mathrm{bA}$ & $14.96 \mathrm{bA}$ \\
\hline
\end{tabular}

Values followed by different letter (small letters in lines and capital letters in columns) were different by Duncan test $(\alpha=0.05)$

$\mathrm{DAI}=$ days after irradiation and storage at $11 \pm 1^{\circ} \mathrm{C} \quad \mathrm{DRT}=$ days at room temperature $\left(24 \pm 2^{\circ} \mathrm{C}\right)$

Table 2 - Firmness (N) of papaya as a function of irradiation and conservation period.

\begin{tabular}{lcccc}
\hline & \multicolumn{4}{c}{ Conservation period } \\
\cline { 2 - 5 } Irradiation & $1 \mathrm{DAI}$ & $14 \mathrm{DAI}$ & $14 \mathrm{DAI}+3 \mathrm{DRT}$ & $14 \mathrm{DAI}+6 \mathrm{DRT}$ \\
\hline $0.0 \mathrm{kGy}$ & $26.33 \mathrm{aA}$ & $19.99 \mathrm{bA}$ & $13.81 \mathrm{cB}$ & $6.24 \mathrm{~dB}$ \\
$0.75 \mathrm{kGy}$ & $22.51 \mathrm{aA}$ & $19.65 \mathrm{aA}$ & $19.30 \mathrm{aA}$ & $12.66 \mathrm{bA}$ \\
\hline
\end{tabular}

Values followed by different letter (small letters in lines and capital letters in columns) were different by Duncan test $(\alpha=0.05)$ $\mathrm{DAI}=$ days after irradiation and storage at $11 \pm 1^{\circ} \mathrm{C} \quad \mathrm{DRT}=$ days at room temperature $\left(24 \pm 2^{\circ} \mathrm{C}\right)$ 
The delay in ripening in irradiated fruits can occur due to the lower capacity of these fruits in producing ethylene, since this hormone has a stimulation role in the general metabolism, and seems to be implicated in the activation and regulation of some enzymes involved in ripening (Gomez et al., 1999). D'Innocenzo (1996) explained that papaya irradiation caused decrease in the activity of the enzymes pectinametilesterase, poligalacturonase and b-galactosidase, responsible for the solubilization of pectins that preserves fruit firmness along the ripening process.

Stage of maturation at the moment of harvest did not affect the efficiency of irradiation preservation of firmness of papayas, contradicting other authors. Irradiation efficiency to delay ripening is lost, if it is applied after the beginning of the climacteric ascension, which means, less than 25\% yellow (Urbain, 1986; Bleinroth, 1995). Loaharanu (1971) acknowledged that irradiation stimulated ripening of papayas when treated in the climacteric ascension period. In another lot, irradiation delayed ripening in papayas still green in the preclimacteric phase. However, the best results of firmness preservation obtained by Zhao et al. (1996) happened to papayas 25 to $30 \%$ yellow. Irradiating papayas mature green and $1 / 4$ yellow, resulted in firmness preservation after seven days of storage at temperatures of 25 , 15 and $12^{\circ} \mathrm{C}$, but not at $10^{\circ} \mathrm{C}$ (Miller \& McDonald, 1999).

The evaluation of skin color in papaya was done through the evaluation of hue angle $\left({ }^{\circ} \mathrm{h}\right)$ where values above $100^{\circ}$ represented green colors and values below $90^{\circ}$ yellow colors. It was verified that papayas ripened normally (Table 1). There was no interaction between irradiation and hue angle, which indicates that irradiation did not inhibit color development. Zhao et al. (1996), Moy et al. (1973), and Akamine \& Wong (1966), also reported that irradiation kept fruits firm, but did not delay color development. However, when chroma $\left(\mathrm{C}^{*}\right)$, that determines intensity of color, and color lightness $\left(\mathrm{L}^{*}\right)$, that determines how dark or light the color is, were analyzed, there was difference between irradiated and non-irradiated samples in the $3^{\text {rd }}$ analysis period (Table $3)$. Irradiated papaya achieved lighter and more intense color before the non-irradiated control, giving the impression that yellow color developed more rapidly. Ramli \& Yusof (1992) and the Instituto de Tecnologia de Alimentos (1987) also observed that irradiated papaya ripened in a more homogenous way, since smaller number of persistent green spots, which would not turn yellow with ripening, were found in irradiated papaya. The internal color of papaya in the variables chroma $\left(\mathrm{C}^{*}\right)$ and lightness $\left(\mathrm{L}^{*}\right)$ did not suffer any effect from treatments.

Papaya harvested as stages of maturation 1 and 2 had higher percentage of soluble solids content, but by reaching senescence, these values decreased (Table 1). Since one of the main components of quality of papaya is sugar content (Akamine \& Goo, 1971), it is important that papaya should be harvested more mature and, if possible, in the maturation stage that elicits higher sugar concentration. The soluble solids contents did not suffer effect of irradiation, as also reported by Moy et al. (1973) and Miller \& McDonald (1999). Irradiated fruits with higher starch content, like banana and mango, suffer alterations in soluble solids (Thomas, 1986). However, the amount of starch in papayas is very low (Selvaraj et al., 1982); therefore, there was no room for alteration in sugar content.

Values of $\mathrm{pH}$ decreased as storage period increased (Table 4), and there was no influence of irradiation in the pH of papayas. Moy et al. (1973) and Miller $\&$ McDonald (1999) also demonstrated that there was no modification of titratable acidity and $\mathrm{pH}$ in papaya which suffered irradiation treatment.

Irradiation can break chemical bonds, increasing membrane permeability and metabolic activity, which will lead to more water vapor movement to intercellular space, and then through cuticle, increasing transpiration (Maxie et al., 1971). However, there was no effect of mass loss due to irradiation in the three maturation stages analyzed. There was only gradual mass loss of papaya as it ripened (Table 4). Miller \& McDonald (1999) also did not confirm difference in mass loss between irradiated and non-irradiated papaya in two maturation stages (mature green and 25\% ripe).

Table 3 - Values of color lightness $\left(\mathrm{L}^{*}\right)$ and chroma $\left(\mathrm{C}^{*}\right)$ of external color of papaya in function of irradiation and conservation period.

\begin{tabular}{lccccc}
\hline & & \multicolumn{4}{c}{ Conservation period } \\
\cline { 2 - 5 } Color variables & Irradiation & $1 \mathrm{DAI}$ & $14 \mathrm{DAI}$ & $14 \mathrm{DAI}+3 \mathrm{DRT}$ & $14 \mathrm{DAI}+6 \mathrm{DRT}$ \\
\hline Lightness & $0.0 \mathrm{kGy}$ & $52.50 \mathrm{cA}$ & $55.93 \mathrm{bA}$ & $64.19 \mathrm{aB}$ & $65.87 \mathrm{aA}$ \\
& $0.75 \mathrm{kGy}$ & $51.50 \mathrm{cA}$ & $58.06 \mathrm{bA}$ & $66.85 \mathrm{aA}$ & $66.32 \mathrm{aA}$ \\
\multirow{2}{*}{ Chroma } & $0.0 \mathrm{kGy}$ & $41.67 \mathrm{dA}$ & $46.13 \mathrm{cA}$ & $56.85 \mathrm{bB}$ & $62.00 \mathrm{aA}$ \\
& $0.75 \mathrm{kGy}$ & $40.89 \mathrm{dA}$ & $48.73 \mathrm{cA}$ & $60.46 \mathrm{bA}$ & $62.81 \mathrm{aA}$ \\
\hline Values followed by different letter $($ small letters in lines and capital letters in columns) were different by Duncan test $(\alpha=0.05)$
\end{tabular}

Values followed by different letter (small letters in lines and capital letters in columns) were different by Duncan test $(\alpha=0.05)$

$\mathrm{DAI}=$ days after irradiation and storage at $11 \pm 1^{\circ} \mathrm{C} \quad \mathrm{DRT}=$ days at room temperature $\left(24 \pm 2^{\circ} \mathrm{C}\right)$ 
Table 4 - Mass loss and $\mathrm{pH}$ of papaya in function of conservation period.

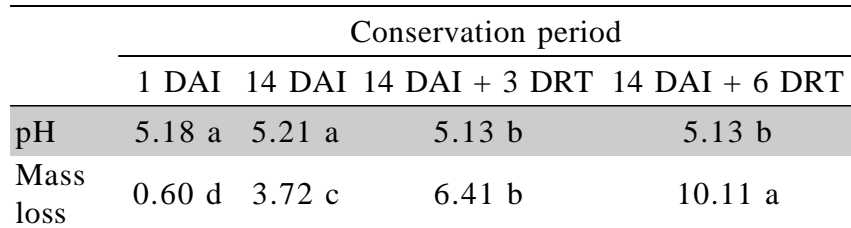

Values followed by different letter were different by Duncan test $(\alpha=0.05)$

$\mathrm{DAI}=$ days after irradiation and storage at $11 \pm 1^{\circ} \mathrm{C}$

DRT $=$ days at room temperature $\left(24 \pm 2^{\circ} \mathrm{C}\right)$

\section{ACKNOWLEDGMENTS}

To Geraldo Antonio Ferreguetti Caliman Agrícola S/A for supplying of papayas, and to Prof. Dr. Angelo Pedro Jacomino for valuable advice and permission to use the laboratory of post-harvest of fruits and vegetables of the Department of Vegetal Production, USP/ESALQ.

\section{REFERENCES}

AKAMINE, E.K.; GOO, T. Relationship between surface color development and total soluble solids in papaya. HortScience, v.6, p.567-569, 1971

AKAMINE, E.K.; GOO, T. Respiration, ethilene production and shelf life extension In irradiated papaya fruits after storage under simulated shipping conditions. Technical Bulletin of the Hawaiian Agricultural Experimental Station, n.93, p.1-12, 1977.

AKAMINE, E.K.; WONG, R.T.E. Extending the shelf life of papayas with gamma irradiation. Hawaiian Farm Science, v.15, p.4-6, 1966.

AZEVEDO, L.A.S. Manual de quantificação de doenças de plantas. São Paulo: O autor, 1998. 114p.

BLEINROTH, E.W. Determinação do ponto de colheita. In: BRASIL. Ministério da Agricultura e da Reforma Agrária. Mamão para exportação: procedimentos de colheita e pós-colheita. Brasília: EMBRAPA, SPI, 1995. p.10-25. (Série Publicações Técnicas FRUPEX, 14).

BRASIL. Ministério da Integração Nacional. Mamão. Brasília: MI, Secretaria de Infra-Estrutura Hídrica, 2000. 8p. (FrutiSéries, 7 Minas Gerais).

CLARKE, I.D. Effects of radiation treatments In: HULME, A.C. The biochemistry of fruits and their products. London: Academic Press, 1971. v.2, cap.20, p.687-705.

D'INNOCENZO, M. Comportamento de enzimas da parede celular e textura da polpa relacionados ao tratamento de irradiação de mamões (Carica papaya L. Cv solo) durante o amadurecimento. Piracicaba: USP/ESALQ 1996. 85p. (Dissertação - Mestrado).

FAO. FAOSTAT Agriculture Data. Roma, 2002. http://apps.fao.org/cgibin/nph-db.pl?subset=agriculture. (04 nov. 2002)
GOMEZ, M.L.P.A.; LAJOLO, F.M.; CORDENUNSI, B.R. Metabolismo de carboidratos durante o amadurecimento do mamão (Carica papaya L. cv. Solo): influência da radiação gama. Ciência e Tecnologia de Alimentos, v.19, p.246-252, 1999.

INSTITUTO DE TECNOLOGIA DE ALIMENTOS - ITAL. Conservação de mamão por meio da radiação gama de cobalto 60 . Campinas: ITAL, $1987.77 \mathrm{p}$

LOAHARANU, P. Recent research on the influence of irradiation of certain tropical fruits in Thailand. In: INTERNATIONAL ATOMIC ENERGY AGENCY. Disinfestation of fruit by irradiation Vienna: IAEA, 1971. p.113-124.

MALAVASI, A. Papaia amplia mercado no exterior. Jornal da USP, 17 jun. 1996. p.6.

MAXIE, E.C.; SOMMER, N.F.; MITCHELL, F.G. Chemical, economic, physical and physiological limitations to irradiation of fruits. In: INTERNATIONAL ATOMIC ENERGY AGENCY. Disinfestation of fruit by irradiation Vienna: IAEA, 1971. p.93-100.

McGUIRE, R.G. Reporting of objective colour measurements HortScience, v.27, p.1254-1255, 1992.

MILLER, W.R.; McDONALD, R.E. Irradiation, stage of maturity at harvest and storage temperature during ripening affect papaya fruit quality. HortScience, v.34, p.1112-1115, 1999.

MOY, J.H. Potential of gamma irradiation of fruits: a review. Journal of Food Technology, v.12, p.449-457, 1977

MOY, J.H.; AKAMINE, E.K.; WENKAN, N.; DOLLAR, A.M.; HANAOKA, M.; KAO, H.Y.; LIU, W.L.; RIVETTI, L.M. Tolerance, quality, and shelf life of gamma irradiated papaya grown in Hawaii, Taiwan and Venezuela. In: INTERNATIONAL ATOMIC ENERGY AGENCY. Radiation preservation of food. Vienna: IAEA, 1973. p.375-387.

PAULL, R.E. Ripening behaviour of papaya (Carica papaya L.) exposed to gamma irradiation. Post-Harvest Biology and Technology, v.7, p.35970, 1995.

RAMLI, H. bin; YUSOF, N. binti. Effects of irradiation on the organoleptic quality and ripening process of papaya. Jurnal Sains Nuklear Malaysia, v.10, p.25-35, 1992.

SELVARAJ, Y.; PAL, D.K.; SUBRAMANYAM, M.D.; IYER, C.P.A. Changes of chemical composition of four cultivars of papaya ( Carica papaya L.) during growth and development. Journal of Horticultural Science, v.57, p.135-143, 1982.

THOMAS, P. Radiation preservation of foods of plant origin. Part III Tropical fruits: bananas, mangoes e papayas. CRC Critical Reviews in Food Science and Nutrition, v.23, p.147-205, 1986.

URBAIN, W.M. Food irradiation. Orlando: Academic Press, 1986. 351p.

YASIR, M.S. The effect of gamma radiation on the chemical content, texture and shelf life of papaya. Jurnal Sains Nuklear Malaysia, v.8, p.1523, 1990.

ZHAO, M.; MOY, J.; PAULL, R.E. Effect of gamma-irradiation on ripening papaya pectin. Postharvest Biology and Technology, v.8, p.209-222, 1996.

Received February 07, 2003

Accepted January 30, 2004 